\title{
THE ACCOUNTING PROFESSION: SERVING THE PUBLIC INTEREST OR CAPITAL INTEREST?
}

\author{
Associate Professor Mary A Kaidonis, \\ School of Accounting and Finance \\ University of Wollongong, Wollongong NSW 2522, Australia. \\ Telephone: 0242213681 \\ Fax: 0242214297 \\ Email: maryk@uow.edu.au
}

\begin{abstract}
As an integral facet of society, the accounting profession has a role in the State and the corporate sector, and is also expected to serve the public interest. The capacity for the Australian accounting profession to serve the public interest is considered in the context of legislation and the accounting standard setting process. Specific reference is made to the CLERP Act 1999 and ASIC Act 2001. It is argued that the combined effect of these Acts is to legislate bias so that accounting standards privilege the specific needs of holders of capital, that is capital interest. The assumption that capital markets are surrogate for the public interest is contested. Accordingly, if the accounting profession follows national objectives to support capital markets, it may undermine its role in serving society.
\end{abstract}

Key words: profession; public interest; capitalism

\section{INTRODUCTION}

It is widely acknowledged that the "accounting profession is an important facet of our society" (Wyatt, 2004, p 53). Accounting has emerged from society and can be said to be socially constructed and socially constructing (Hines 1988) and can be taken to mean that accounting influences society as well as accounting is influenced by society. This concept of influence was considered by Zeff (1978) who discussed the impact on accounting if accounting standards were designed to avert any "potential adverse" economic consequences. To do so, Zeff (1978) argued would invite a "political resolution" to be "imposed by outside forces” ( $p$ 223) on standard setters, and thus undermine the role of the accounting profession. The issue of influence was also discussed by Solomons (1978), this time in terms of the politicization of accounting where governmental policies can be reflected in accounting standards. Solomons (1978) concluded that the accounting profession should not confuse its role in striving for representational faithfulness of accounting standards with accommodating "national objectives", otherwise "we greatly diminish our capacity to serve our society, and in the long run everybody loses" (p 234). This paper questions whether the Australian accounting profession's capacity to serve society, the public interest, has been diminished.

The capacity for the Australian accounting profession to serve the public interest will be considered in the context of two specific changes in the corporate arena; being the Corporate Law Economic Report Program Act (1999) and the Australian Securities and Investment Commission Act 2001. Specific sections have had an impact on accounting standard setting and ultimately there are implications for the accounting profession. This 
paper starts with a brief discussion of a profession and its relationship to the State, the corporate sector and the public. This will form a framework against which to consider the legislative events and their impact on the accounting profession and its capacity to serve the public interest.

\section{PROFESSIONS, PRIVILEGE AND PUBLIC INTEREST}

According to Wyatt "the public rightfully expects" (2004, p 52) the accounting profession to be practical, intellectual and to have regard for the public. These characteristics have been essential in defining any profession in the last century or so (Cogan 1953, Goode 1957) and upholding these characteristics is how the accounting profession has been expected to serve the public interest.

In serving the public, it is imperative that professions have and demonstrate a systematic and elite knowledge. Over the last 50 years, the importance of a systematic knowledge has remained axiomatic to defining a profession (see Greenwood 1957, Wikepedia 2008a). The unique knowledge claims of a profession are reflected in the practical and intellectual characteristics of a profession which require "the use of skills based on theoretical knowledge ...[and] ... education and training in these skills", as well as "the competence of professionals ensured by examinations" (Millerson 1964 quoted in Abercrombie et al 1984, p 196). An important aspect of professions is that they are ascribed status or a "privileged position” (Richardson, 1988, p 381) by society. More importantly this privileged position also gives the profession authority in the society and the authority for self regulation (Abercrombie et al, 1984). Indeed, professions represent "one of the most fundamental forms of legitimacy" (Esland, 1980, p 218). This privilege and legitimacy is accompanied by responsibilities to the public, generally expressed by codes of conduct. Professions have "a code of conduct to ensure professional integrity ... [in the] ... performance of a service that is for the public good” (Millerson 1964 quoted in Abercrombie et al 1984, p 196). Indeed “(o)ne of the most important features of professional practice ... is the service ethic" (Esland, 1980, p 219). The accounting profession's service ethic is reflected in codes of conduct and their knowledge claims emanate from its accounting standards, legal requirements and professional guidelines which are acquired by formal education and training (Richardson, 1988).

The Australian accounting profession's APES 110: Code of Ethics for Professional Accountants which, like the former Codes of Professional Conduct stated that "(a) distinguishing mark of a profession is its acceptance of its responsibility to the public interest” (Accounting Professional and Ethical Standards Board, 2006, p 4). The introductory section of APES 110 also defined public interest as "the collective wellbeing of the community of people and institutions that the members serve" (Accounting Professional and Ethical Standards Board, 2006, p 4). The term public interest usually refers to "common wellbeing" or "general welfare" even though there may be many co-existing views of what constitutes common well-being (Wikepedia 2008b). Public interest can be assumed to be an amalgam of many competing views whether these are of individuals, majority groups or minority groups. Corporations are also implicated in public interest and could have similar or competing interests to those of individuals or groups.

\section{THE PROFESSION, THE STATE AND CAPITAL MARKETS}

Richardson (1989) also considered the accounting profession in the context of economic markets, not just the State and the community. Indeed, he described the accounting profession as facilitating and being facilitated by a nexus between the State, economic markets and community forces (Richardson 1989). This facilitation is also consistent with accounting being described as socially constructed and socially constructing (Hines 1988). 
However, accompanying the characteristics of professions, sociologists and other commentators have described professionalism as encoding "political rhetoric" (Richardson, 1988, p 381) which helps to legitimize the laws and practices which sustain professions.

The professionalisation of accounting occurred in the nineteenth century and is closely linked to the introduction of the Companies Act 1856 for the financial regulation of British business entities (Portwood and Fielding, 1981). The growth in professional practices was noted as being consistent with the "growth of international corporate capitalism and its concomitant institutions" (Portwood and Fielding, 1981, p 756). According to this perspective, corporate interests and accounting professionals' privilege and status are inextricably linked, so much so that it can be argued that professionals "have become agents of capitalist control and also the professionally trained servants of capitalism" (Esland, 1980, p 229). Some have argued that the accounting profession, like other professions is an instrument of the State and that accounting expedites capitalism (Esland 1980, Portwood and Fielding 1981, Richardson, 1989). A long held view is that the accounting profession "overtly serves the interests and ideology of corporate capitalism" (Portwood and Fielding 1981) p 763). In this paper, it will be argued that capital interests are not only overt, but are sanctioned by legislation.

\section{LEGISLATION AND PUBLIC INTEREST}

The CLERP Act 1999 has introduced a number of changes for the business community in general but also brought in structural changes which had an impact on the accounting profession (Ford et al, 2000). Specifically, the creation of the Financial Reporting Council (FRC) as a new administrative layer between the Australian Accounting Standards Board (AASB) and the Federal Attorney General, signalled a change for the accounting profession. According to the ASIC Act 2001 Section 225(2)(a)-(l) the FRC was to offer a broad oversight function, control the business plans and broad strategic plans, monitor the operation of accounting standards and control the budget of the AASB. This meant that the AASB no longer had a direct relationship with the government. There were also explicit restrictions to the powers of the FRC in S 225 (5) which stated that "(t)he FRC does not have power to direct the AASB in relation to the development, or making, of a particular standard" (CCH 2004, p 1,961). However, despite the restriction on the FRC's powers, this event still signals a diminished role of the AASB in respect of international accounting standards. Section 233 (ASIC Act 2001) specifies that the "AASB must comply with the direction" (CCH 2004, p 1,964) given by the Minister, who would first consider advice from the FRC. It should be noted that the members of the FRC are meant to be selected from a broad base and are by appointment by the Minister (Ford et al 2000). The FRC can be seen as helping to uphold the public interest since it is meant to have a broader representation than the membership of the AASB. The potential to uphold the public interest needs to be considered further in the light of the next legislative change still within the ASIC Act 2001. In reference to international financial centres, Section 227 (2) reads:

(i)n carrying out its functions under paragraphs (1)(a) and (d), the AASB must have regard to the interests of Australian corporations which raise or propose to raise capital in major international financial centres (CCH 2004 p. 1,962).

It is important to draw attention to the words "must have regard to" and their implication. The words must have regard to suggest that the AASB must keep in mind or accommodate. Further, the section refers to those raising or proposing to raise capital in foreign markets, that is, refers to a specific group of corporations, and not all companies. This 
can be interpreted to mean that this particular group of corporations' interests are being prioritised over other members of the community, whether they are companies or individuals. Therefore prioritising can privilege specific interests and this is in direct contradiction to the expectations which Solomon's (1978) had noted, that "standard setters are expected to represent the entire constituency as a whole and not be representatives of a specific constituent group” ( $p$ 227). Therefore this Australian legislative event, actually legitimates bias so that accounting standards privilege the specific needs of particular corporations. It follows then, that the accounting profession explicitly serves capital interests.

The ASIC Act 2001 also specifies in Section 231 (1) that the "AASB must carry out a cost/benefit analysis of the impact of a proposed accounting standard" (CCH Australia Limited 2004, p 1,963). This section explicitly requests that economic consequences of accounting standards be part of the accounting standard setting processes, therefore, as part of a legislative instrument, this request is a directive of the State. Earlier in this paper it was noted that Zeff (1978) had warned against accounting standard setters allowing themselves to be influenced by economic consequence arguments. However, in this Australian context, it is the State which is accommodating a "political resolution" (Zeff 1978, p 223) through legislative pathways. The question must therefore be asked, does this undermine the self regulation and expert knowledge that the accounting profession is meant to uphold? If so, how is the public interest protected?

Public interest is rarely a homogeneous set of ideals and there may well be competing interests. Whether meeting the needs of corporations (proposing to raise capital) can be reconciled with other corporations or individual shareholders needs to be considered. Further, one must ask whether these needs can be reconciled with the needs of other members of a community, such as elderly people, indigenous people, disabled people, homeless people, the environment and so on. The interests of these sectors of the community are not directly or explicitly served by satisfying the needs of corporations raising capital in foreign markets. An implicit assumption of CLERP is that the economy of a country is linked and sustained by

capital markets. It can be argued that the interests of capital markets ultimately support the public interest generally. However, if the accounting profession and accounting standard setting is meant to prioritise corporations raising capital, then the expectation that the accounting profession protects the public interest as a whole can not be sustained.

\section{CONCLUSION}

The events discussed above provide evidence that the accounting profession, through legislative instruments is required to prioritise the interests of corporations. It could also be argued that the State is accommodating multinational corporate interests instead of the public interest. Sections in the CLERP Act 1999 and ASIC Act 2001 collectively reflect a bias which is legislated. In doing so, the public interest which is meant to be upheld according to the Accounting Professional and Ethics Standards Board (2006) could be compromised, or as Solomons (1978) warned, the capacity for the profession to serve the public could be diminished. Whether the public interest is served, compromised or diminished, there is no doubt, that the accounting profession, as Richardson (1989) argued, continues to play a pivotal role in the interrelationship between the State and capital markets. 


\section{REFERENCES}

Abercrombie, N., Hill, S. and Turner, B.S. (1984) Dictionary of Sociology, Penguin Books, $2^{\text {nd }}$ edition.

Accounting Professional and Ethical Standards Board, (2006) APES 110 Code of Ethics for Professional Accountants, Accounting Professional and Ethical Standards Board (http://www.cpaaustralia.com.au/cps/rde/xchg/SID-3F57FEDFF6A3388C/cpa/hs.xsl/588_19858_ENA_HTML.htm accessed 17 January 2007).

CCH (2004) Australian Corporations \& Securities Legislation: Corporations Act 2001, ASIC Act 2001, related regulations, CCH Australia Limited, Australia.

Cogan, M. (1953) “Toward a Definition of Profession”, Harvard Educational Review, Vol. XXIII, No 1, pp 3350.

Esland, G. (1980) “Professions and professionalism”, in Esland, G. and Salaman, G. (eds) The Politics of Work and Occupations, The Open University Press, Milton Keynes.

Ford, H.A.J., Austin, R.P., and Ramsay, I.M. (2000) An introduction to the CLERP Act 1999: Australia's new company law, Butterworths, Sydney.

Hines, R.D. (1988), "Financial Accounting: In Communicating Reality, We Construct Reality", Accounting, Organisations and Society, Vol. 13, No. 3, pp. 251-261. https://doi.org/10.1016/0361-3682(88)90003-7

Goode, W. J. (1957) “Community within a Community: the Professions”, American Sociological Review, Vol 22, No 2, pp 194-200. https://doi.org/10.2307/2088857

Greenwood, E. (1957) “Attributes of a Profession”, Social Work, Vol 2, pp 44-55.

Portwood, D. and Fielding A. (1981) "Privilege and the Professions”, The Sociological Review, Vol 29, No 4, pp 749-773. https://doi.org/10.1111/j.1467-954X.1981.tb00774.X

Richardson, A.J. (1988) “Accounting knowledge and professional privilege”, Accounting, Organizations and Society, Vol 13, No 4, pp 381-396. https://doi.org/10.1016/0361-3682(88)90012-8

Richardson, A.J. (1989) "Corporatism and intraprofessional hegemony: a study of regulation and internal social order”, Accounting, Organizations and Society, Vol 14, No 5/6, pp 415-431. https://doi.org/10.1016/0361-3682(89)90009-3

Solomons, D., (1978) “The Politicisation of Accounting”, in Jones, S., Romano C., and Ratnutunga, J. eds (1995) Accounting Theory; a contemporary review, Harcourt Brace, pp 225-235.

Wikepedia (2008a) "Profession” http://en.wikepedia.org/wiki/Profession, accessed 3/06/08.

Wikepedia (2008b) "Public interest” http://en.wikepedia.org/wiki/Public interest, accessed 3/06/08.

Wyatt, A.R. (2004) “Accounting Professionalism - They Just Don’t Get It!”, Accounting Horizons, Vol. 18, No. 1, pp 45 - 53. https://doi.org/10.2308/acch.2004.18.1.45

Zeff, S.A. (1978) “The Rise of 'Economic’ Consequences”, in Jones, S., Romano C., and Ratnutunga, J. eds (1995) Accounting Theory; a contemporary review, Harcourt Brace, pp 216-225. 